\title{
CONCISE TEXTBOOK OF HISTOLOGY FOR UNDERGRADUATE STUDENTS
}

\author{
Dr. Sonia Jaiswal, Prof. P.K. Sharma \\ Department of Anatomy, Era's Lucknow Medical College, Era's University, Lucknow, UP, India
}

Concise Textbook of Histology for Undergraduate Students, authored by Sangeeta M, Varalakshmi KL and Jyothi N Nayak, published by Thieme Medical and Scientific Publishers Private limited. The book was first reprinted in 2018 and next in 2019. The ISBN number is 978-93-86293-749.

Prof. Sangeeta M is the head of the department, Department of Anatomy, MVJ Medical College, Bangalore. She has numerous publications to her credit with more than 14 years of teaching experience. Dr Varalakshmi KL has authored several publications and has a brilliant academic record. The author Jyothi $\mathrm{N}$ Nayak has 6 years of teaching experience and is an active researcher.

The book is written from the perspective of an undergraduate student. The language of the book has been kept simple and is thus easy to understand. The hand drawn diagrams are easy to replicate hence undergraduate students can easily correlate with the images from various slides. There are points of identification and questions given at the end of each chapter which help in a better understanding of the text. I have reviewed the book as follows-

\section{Chapter 1: Microscope}

The chapter on the microscope is concise and to the point. The diagrammatic representation of the microscope is well made and easy to reproduce keeping in mind the undergraduate students. The components of the microscope are properly outlined. The definition of magnification with a difference between resolution and magnification could have been included in the chapter. The function of $40 \mathrm{X}$ magnification on page 2 lacks clarity.

\section{Chapter 2: Tissue Preparation}

The steps of tissue preparation are properly outlined with an excellent flowchart depicting the steps in staining but the term bluing should be explained. The points on tissue collection are correct however the second point on tissue being usually collected from the mouse gives an impression that histology is studied usually in mice only. The instrument used for cutting tissues is not mentioned, simply stating that the tissue is cut by a knife does not solve the purpose. A knife can also give the impression of a kitchen knife. An example of a fixative could have been included in the second point.

\section{Chapter 3: Epithelium}

The chapter has covered the learning objectives to a large extent, an incorporation of a flowchart showing the classification could have been included. The chapter has plenty of editing flaws such as arrows in figure 3.2 point towards the alveoli of the lung instead of the epithelium. Fig 3.3 and 3.4 showing cuboidal epithelium is under the heading of simple columnar epithelium. Fig 3.5 and 3.6 should come under the heading of simple columnar epithelium. Similar glitches are seen with figure 3.7-3.11. 
Figure numbers $3.1,3.3,3.5,3.7,3.13,3.14,3.18,3.19,3.21,3.23$ and 3.24 are not labelled. In fig. 3.15 the arrow points towards a space rather than stratified columnar epithelium.

\section{Chapter 4: Glands}

The chapter is concise and to the point. A flowchart showing the classification of glands could have been included in the chapter. The definition of tubule-alveolar glands lacks clarity and gives the impression of an incomplete sentence. Unicellular glands have not found a place in this chapter.

\section{Chapter 5: Connective Tissue}

Illustrations in the chapter are of good quality. The chapter includes all important features that are taught to undergraduate students.

\section{Chapter 6: Cartilage}

The chapter on cartilage is well written including points of identification which is beneficial for students. Fig 6.1, 6.3, and 6.5 are well drawn diagrams with a proper labelling.

\section{Chapter 7: Bone}

The chapter covers all the important points related to the microscopic anatomy of bone. Fig 7.2, 7.3, 7.4 and 7.5 show a schematic representation of various cells present in the bone. Fig 7.9 and 7.11illustrate the transverse and longitudinal section of the bone under a low magnification but do not mention the names of the stains used.

\section{Chapter 8: Muscles}

The diagrammatic representations shown in fig 8.1, 8.5, 8.6 and 8.7 are very well illustrated especially fig 8.5 which shows the $\mathrm{H}$ band and $\mathrm{Z}$ line. An excellent flowchart showing the steps of muscle contraction has been incorporated in the chapter. Fig 8.9 shows the components of the intercalated disc and is well illustrated. Table 8.1 neatly summarises a comparative account of all three muscle types.

\section{Chapter 9: Nervous Tissue}

The chapter on nervous tissue is well written. Fig 9.2-9.10 are well illustrated,

\section{Chapter 10: Circulatory System}

The chapter covers all the important aspects and justifies the learning objectives meant for an undergraduate student

\section{Chapter 11: Lymphatic Tissue}

The figures in this chapter are very well illustrated. It is very easy to correlate the H\&E pencil drawing with the slides stained with haematoxylin and eosin stain and focussed under low magnification.

\section{Chapters: 12-23}

The text in these chapters is precise and to the point. The diagrams are well drawn and labelled and are in congruity with the images of various slides. 
The authors have done a commendable job in penning down this book. With a few simple moderations the book in times to come will be an excellent guide to comprehend the complexities of cellular morphology. 